\title{
Mining and petroleum boom and public spending policies in Niger: a dynamic computable general equilibrium analysis
}

\author{
Saadatou Sangare ${ }^{1}$ and Hélène Maisonnave ${ }^{2 *}$ \\ ${ }^{1}$ Cellule d'Analyse des Politiques et d'Evaluation de l'Action Gouvernementale (CAPEG), Niamey, Niger \\ and ${ }^{2}$ PEP Network and Department of Economics, Université Le Havre, Le Havre, France \\ ${ }^{*}$ Corresponding author. Email: hmaisonnave@hotmail.fr
}

(Submitted 14 September 2017; revised 15 February 2018; accepted 20 February 2018;

first published online 3 May 2018)

\begin{abstract}
This study analyzes a public-spending option from mining and oil resources and its impact on Niger's economy. The windfall gain from mining and oil revenues provides an opportunity for the country to reinvest natural resource rents, enhance economic development, and address infrastructure gaps. Drawing on the country's recent and expected mining and oil exploitation, we evaluate the effects of a reinvestment policy in road infrastructure using a dynamic computable general equilibrium (CGE) model. We find that investment in road infrastructure brings positive spillover effects to other sectors of the economy and benefits to the economy in the long run. Our analysis additionally shows that reinvestment in road infrastructure, given the initial state of infrastructure in Niger, could help mitigate the resource curse.
\end{abstract}

Keywords: CGE; economic development; Natural resources; Niger

JEL Classification: C68, J23, O13, Q18

\section{Introduction}

Natural resources can provide opportunities for economic development. For many developing countries, natural-resource revenues have been an important source of government income (Berg et al., 2013), though all face similar constraints: the level of infrastructure is poor, with paved roads comprising 27 per cent of total roads; domestic tax collection is very low; and the population living below the poverty headcount (US $\$ 2$ per day or less) is around 60 per cent (IMF, 2012b). Price increases in natural resource and new mineral discoveries could, therefore, generate significant fiscal income which, if well managed, could finance public investment and enhance economic development.

Niger is one of the 29 resource-rich developing countries identified by the International Monetary Fund (IMF, 2012b), and new exploitation of uranium and petroleum deposits in Niger is generating substantial additional revenue. Fiscal revenues from 
mining represented 13 per cent of government income in 2012, a figure that rose to 26 per cent in 2016 (INS, 2013). These extra financial resources should ease government budgetary constraints and support an increase in public investment and job creation. Despite its abundant natural resources, however, Niger is one of the poorest countries of the world. The country is ranked 187 among 188 countries on the Human Development Index (UNDP, 2017). With a per capita annual income of barely US $\$ 420$ in 2015 (World Bank, 2016), the country is characterized by a weak infrastructure and the predominance of an agricultural sector.

The exploitation of uranium is carried out by two subsidiaries of the French nuclear group AREVA and the Société des Mines d'Azelik. In 2009, AREVA obtained rights to exploit the Imouraren deposit (starting in 2017) which has estimated reserves of 200,000 tons, for an estimated annual production of between 5,000 and 6,000 tons. Exploitation of this deposit (the largest in Africa) will make Niger one of the largest producers in the world.

In addition to uranium, the production of oil began in 2011. Operations are governed by a production-sharing agreement between the Government of Niger (40 per cent) and the China National Petroleum Company (60 per cent). The operating contract enabled development of the Agadem oil field and construction of the Zinder refinery, which is linked to the oilfields by a pipeline. The refinery has a capacity of 20,000 barrels per day and produces gasoline, diesel and liquefied gas (IMF, 2015). By 2017, total oil production will reach 80,000 barrels/day, 60,000 of which will be exported through a pipeline via Chad. The oil reserves, initially estimated at about 300 million barrels, have reached 750 million barrels (Banque de France, 2014).

The risks most commonly associated with expanding extractive resources are weak management capacity and absorption of revenues. These risks are linked to realexchange-rate appreciation and a loss of competitiveness of tradable sectors outside of natural resources (Dutch disease). To face these challenges, the Niger government plans to use mining and petroleum revenues to finance public infrastructure, agriculture, health care and education (IMF, 2012a). The dearth of infrastructure in developing countries contributes hugely to low factor productivity. For example, repeated electrical outages, problems with communications systems, and insufficient quantity and quality of roads are all impediments to investment, growth and poverty-reduction in these countries (World Bank, 2002).

According to Domínguez-Torres and Foster (2011), infrastructure (electricity, telecommunications and road infrastructure) in Niger contributes little to economic growth. Indeed, infrastructure only contributed 0.3 percentage points to per capita growth performance of the country between 2000 and 2005. This poor performance is among the lowest on the continent. Domínguez-Torres and Foster (2011) point out that improving road conditions (especially through maintenance) would enhance trade and boost economic growth by 1.71 percentage points. Indeed, in 2015, the national road network included $20,140 \mathrm{~km}$ of roads, of which $4,469 \mathrm{~km}$ were paved roads, $8,544 \mathrm{~km}$ were modern unpaved roads and $6,288 \mathrm{~km}$ were rural roads. The rest of the roads are in poor condition (Ministère du Plan, 2017). Despite an improvement in the number of good quality roads in the country, major shortcomings persist with regard to road quality, poor coverage of the country and road overload. For instance, one of the causes of road conditions is the overloading of trucks. Indeed, given the small number of trips per month, trucks tend to maximize their load. As pointed out by Domínguez-Torres and Foster (2011), without periodic maintenance, a significant portion of the road network could be in poor condition in a short period of time. 
Moreover, evidence from surveys of private businesses suggests that they perceive Niger's poor infrastructure not only as a bottleneck that stifles growth, but as the worst among West African countries (Domínguez-Torres and Foster, 2011). To surmount infrastructure challenges, Niger must increase spending on road infrastructure over the next decade, and reinvestment of a portion of mining revenues to this end would bring positive outcomes.

Using a dynamic computable general equilibrium (CGE) model calibrated on a 2012 Social Accounting Matrix - which takes into account uranium, crude oil and refined oil this paper examines the potential impact on Niger's economy if extraction revenues were directed toward infrastructure. Because a dynamic CGE makes it possible to account for actions and redistribution efforts across sectors over time, it is the appropriate tool for capturing the long-term effects and implications of a reinvestment policy.

The remainder of the paper is organized as follows. Section 2 presents the literature review. Section 3 presents the data and the model, while section 4 presents the scenarios and the results. Section 5 concludes.

\section{Literature review}

An abundant literature exists on natural resources and economic development, including discussions regarding whether natural resources contribute to economic development or, conversely, can become a curse (Sachs and Warner, 1995).

For many authors, the impact of the exploitation of natural resources is only considered positive if those resources are used to improve infrastructure, human capital such as education and health, and good governance (Acemoglu et al., 2003) or to increase productive investments or spending (Sachs and Warner, 2001; Esfahani and Ramirez, 2003; van der Ploeg and Poelhekke, 2009; van der Ploeg, 2011; Estache et al., 2012).

On the other hand, poor management of extractive resources also negatively affects growth and competitiveness in non-extractive sectors (Sachs and Warner, 1999, 2001; Gylfason and Zoega, 2001; Collier et al., 2010; Arezki et al., 2012). In addition, as van der Ploeg and Poelhekke (2009) explain, a landlocked country with a poor financial system (such as Niger) is more likely to suffer from price volatility and, therefore, to experience the resource curse.

Investment in infrastructure is considered favorable to potential economic growth because such investment increases capital accumulation and total-factor productivity (Alter et al., 2016). The link between public infrastructure and economic growth is the subject of a significant number of studies (see Ayogu, 2007 and Ajakaiye and Ncube, 2010 for reviews). Some show that public infrastructure is necessary to increase agricultural productivity (Esfahani and Ramirez, 2003), while others address the efficiency with which existing capital stocks are used by citizens (Calderón and Servén, 2008).

Bourguignon and Sundberg (2006) showed that Dutch-disease effects could be overturned for Ethiopia if productivity spillovers were extended to all sectors. Adam and Bevan (2006) for Uganda and Levy (2007) for Chad showed that Dutch disease could be avoided if non-tradable sectors benefited from infrastructure investment externalities as well. These results were confirmed for the Philippines by Savard (2010) and for six African countries by Estache et al. (2012).

Using a dynamic CGE for Uganda, Bategeka and Matovu (2011) found important productivity gains in the extractive sector, which led to a significant reduction in poverty in rural areas. Wiebelt et al. (2011) analyzed different spending strategies for oil revenues in Uganda and highlighted the fact that poverty reduction and economic benefits in 
agriculture increased, while income disparities between rural and urban areas decreased, when extractive resources were used to increase public investments in agriculture and overcome chronic under-investment in public goods.

Go et al. (2016) used a dynamic CGE model for Niger to evaluate the implications of spending options proposed in recent literature on Dutch disease. They evaluated various spending scenarios (a transfer to households and an increase in public spending on education and health) under a range of resource-revenue-management strategies. One management strategy consists of placing all natural-resource revenues in a sovereignwealth fund, from which the economy benefits only via the interest earned on the fund (the bird-in-hand strategy). Go et al. (2016) also evaluated two scenarios under the permanent-income hypothesis (i.e., a constant level of income is achieved every year) and a short-term borrowing strategy to raise consumption and investment. They found that the transfer scenario had a greater impact on poverty reduction in the short term and that investment in human capital took longer to show effects. They found little difference in real consumption across the three different spending strategies. Our study complements the Go et al. (2016) analysis because it evaluates the effects of road infrastructure investment on the economy, following the priorities established under the new Social and Economic Development Plan (PDES) for the period 2017-2021 (Ministère du Plan, 2017).

\section{Data and methodology}

The Social Accounting Matrix (SAM) was built with 2012 data. It includes ten sectors and commodities (agriculture, livestock, uranium, petrol, petroleum products, other mining, manufacturing, electricity, construction, services, and administration); three broad factors (capital, skilled labor, unskilled labor); four institutional accounts (households, firms, government, and the rest of the world); and one savings and investment account.

Households are further disaggregated into six types (farmers, breeders, public employees, private employees, informal workers, inactive workers) using the National Survey of Living Conditions of Households (INS, 2014). Household classification is made according to the socioeconomic category of the head of the household.

Along with the SAM, some additional data were required, including elasticities. Income and trade elasticities were taken from Sangaré et al. (2015) while substitution elasticities in production functions were borrowed from Annabi et al. (2006).

In terms of modelling, we used the dynamic CGE model developed by Decaluwé et al. (2013). Though the authors fully described their model, we provide its main characteristics and describe the changes we introduced to reflect the actual context of Niger more accurately.

As mentioned, the CGE model includes ten activities and commodities, in line with the SAM. Production-function technology is assumed to be of constant returns to scale and is presented in a two-level production process. At the first level, output is a Leontief input-output of value-added and intermediate consumption. At the second level, a constant elasticity of substitution (CES) function is used to represent the substitution between composite labor and capital. Labor is further disaggregated into skilled and unskilled workers.

Households were disaggregated by occupation, and the model distinguished among three sources of income: labor income (salaries and wages), capital income, and transfers from institutional sectors (households, firms, government, and the rest of the world). Households use their income to pay taxes, transfer to other institutions, consume, and 
save. On the demand side, final household consumption is represented by a linear expenditure system-type demand function derived from a utility-maximization process under a household budget constraint.

Private business income is equal to those firms' share in capital income by sector plus transfers from other institutions. After paying income tax and dividends to other institutions, a firm's remaining income constitutes savings. Government income is composed of direct taxes paid by households and businesses, import tariffs, indirect taxes on domestic sales, transfers from other institutions, and a share of capital income. Government savings is equal to government income less consumption and transfers paid to other institutions.

To model international trade, we used the traditional CGE-modelling approach. We assumed that Niger was a small country, facing a finite elasticity on its export demand. In other words, to increase their shares on the international market, producers in Niger would need to become more competitive.

In order to account for the specificities of Niger, and in keeping with the purpose of our study, we introduced unemployment into the model. Indeed, Nigerien unemployment is estimated at 24.1 per cent for skilled workers and 17.8 per cent for unskilled workers (INS, 2016). To model that condition, we followed Blanchflower and Oswald (1995), who showed the existence of an empirical relationship between wages and unemployment, expressed as a negative slope.

Our model accounted for spillover effects of infrastructure investment on the other sectors of the economy. Following Chitiga et al. (2016), we introduced a productivity factor to investment in infrastructure. As mentioned, the value-added for each sector is a CES composite of composite labor and capital. We added a productivity factor related to the stock of infrastructure to the function. The resulting equation is:

$$
V A_{j, t}=\left(\frac{K D_{t}^{I N F}}{K D_{t-1}^{I N F}}\right)^{\sigma_{j}^{I N F}} B_{j}^{V A}\left[\beta_{j}^{V A} L D C_{j, t}^{-\rho_{j}^{V A}}+\left(1-\beta_{j}^{V A}\right) K D C_{j, t}^{-\rho_{j}^{V A}}\right]^{-1 / \rho_{j}^{V A}}
$$

where:

$V A_{j, t}:$ value-added of sector $j$

$K D_{t}^{I N F}$ : infrastructure stock at period $t$

$L D C_{j, t}$ : sector $j$ 's aggregate labor demand

$K D C_{j, t}$ : demand for composite capital by sector $j$

$B_{j}^{V A}:$ scale parameter (CES - value-added)

$\beta_{j}^{V A}$ : distributive parameter (CES - value-added)

$\rho_{j}^{V A}$ : elasticity parameter (CES - value-added)

$\sigma_{j}^{I N F}$ : elasticity - productivity and infrastructure

Therefore, investment in infrastructure should increase the stock of infrastructure capital $\left(K D_{t}^{I N F}\right)$ of the economy (roads, airports, etc.) in the following year.

This type of investment would not increase the stock of capital in any specific sector and can be considered a public good. We assumed that investment in infrastructure, however, would have an impact on other sectors: a new bridge, for example, could reduce travel time for all the sectors of the economy. It is important to point out that we do not 
take into account the direct effect through the demand addressed to the activities which provide the goods for the road infrastructure improvements.

The value of the elasticity was taken from Vanduzai and Chitiga (2017). They borrowed the value from Fedderke and Bogetić (2006), who found that a 1 per cent increase in investment in economic infrastructure increases total factor productivity (TFP) growth by 0.04 percentage points.

In addition to investment in infrastructure, our analysis included maintenance costs for the increase in public investment, following Estache et al. (2012). As DomínguezTorres and Foster (2011) pointed out, Niger's budget for road maintenance was 70 per cent below the amount required. Maintenance cost was added to public spending proportionally to the magnitude of the investment. The value attributed to the specific cost was taken from Fay and Yepes (2003).

In terms of closure rules, we assumed that the nominal exchange rate was the numeraire. Because Niger is a small country, world prices were considered exogenous. Factor supplies are fixed in the first period; the labor force subsequently grows at the same rate as population, and capital growth is modeled using an accumulation equation (Jung and Thorbecke, 2003). Transfers between institutions and household minimal consumption in volume are fixed at the base year and then grow at the population rate. Savings for the rest of the world was fixed on the assumption that Niger could not borrow from the rest of the world.

\section{Scenarios and results}

\subsection{Scenarios}

As explained above, given the weak initial stock of infrastructure, an investment plan is needed to accelerate growth and increase productivity in all sectors. Following the Social and Economic Development Plan (PDES), therefore, our scenario evaluated the impact of an increase in road-infrastructure investment of 3 per cent each year from 2017 to 2022. The 3 per cent rate takes into account the goal of the Renaissance Programme (2016-2021) which is to build $2700 \mathrm{~km}$ of new roads.

The investment scenario was compared to the reference scenario, also called the business as usual (BAU) scenario. This reference scenario accounted for the increase in uranium and petroleum production and exports forecast by the Ministry of Mining and Petroleum, as well as the IMF's forecasted increase in GDP beginning in 2012 (the base year of our SAM). It was assumed that exports of crude oil (60,000 barrels/day) would begin in 2017 and that a substantial increase in uranium production would come from the Imouraren mine in 2019. These projected increases should generate mining and petroleum revenues: royalties and taxes paid by mining and oil companies, dividends received by the government as a shareholder, and taxes on business profits. It is important to note that the reference scenario was very positive for Niger's economy. Mining-sector growth increased fiscal revenues, which in turn increased government income and savings and therefore total investment in the economy. In other words, in this reference scenario, there was no government intervention in economic policy. We present both short-term (one year after the introduction of the investment plan, or 2018) and long-term (2022) results.

\subsection{Analysis of simulation results}

Generally speaking, public investments in road infrastructure affect the economy in two ways. On the demand side, they increase public spending (maintenance costs), which 
Table 1. Impact on macroeconomic variables (\% change from the BAU)

\begin{tabular}{lcc} 
& Short-Term & Long-Term \\
\hline Real GDP & 0.05 & 0.04 \\
\hline Real household consumption & 0.02 & 0.03 \\
\hline Consumer price index & -0.03 & -0.02 \\
\hline Skilled unemployment & -0.14 & -0.1 \\
\hline Unskilled unemployment & -0.05 & -0.02 \\
\hline
\end{tabular}

leads to an increase in aggregate demand, which drives income. On the supply side, they reduce production costs, facilitate integration of production areas and markets into the broader economy, and increase efficiency and productivity. Given Niger's landlocked situation and its poor infrastructure, government investment in road infrastructure should have a positive impact on the economy as this should improve the conditions of the different sectors of the economy to trade.

\subsubsection{Macroeconomic results}

The effects of road-infrastructure investment in the simulation are favorable for the economy, both in the short and long term. Indeed, real GDP increases by 0.05 per cent and 0.04 per cent, respectively, in the short and long term (table 1). The increase in infrastructure investment improves production in most sectors and leads to a decrease in the consumer price index.

As mentioned earlier, there are two economic reactions to an increase in investment spending: one affects the supply side (activities produce more and can therefore trade more); the other affects the demand side through an increase in public spending. More workers are required to service increased production needs, which leads to a decrease in unemployment for both skilled and unskilled workers. The increase in employment combined with a fall in consumer price index leads to an increase in real household consumption throughout the period.

\subsubsection{Impact by sector}

Production increases in all sectors in the simulation, in both the short and long run (table 2). To produce more, sectors must hire more workers, but the increase in workers would not be uniform across sectors and would depend on the sectoral composition of the labor force. The livestock sector only hires unskilled workers, for example, while the uranium sector intensively employs skilled workers. The increase in production in all sectors, therefore, would have diverse effects on the labor force.

The increase in production is followed by a decrease in prices and an increase in exports for various commodities. Indeed, producers become relatively more competitive in the international market in the simulation, and therefore, can export more. This increase in exports is in line with the expectations of Domínguez-Torres and Foster (2011), who pointed out that increased investment in infrastructure would reduce costs and facilitate trade.

\subsubsection{Impact on institutions}

Macroeconomic changes have an impact on the different institutions. The increase in household income is relatively similar over the period. It increases slightly for all 
Table 2. Impact on production (\% change compared to the BAU)

\begin{tabular}{lcc} 
& Short-Term & Long-Term \\
\hline Agriculture & 0.05 & 0.03 \\
\hline Livestock & 0.05 & 0.03 \\
\hline Uranium & 0.05 & 0.03 \\
\hline Oil & 0.04 & 0.03 \\
\hline Refined petroleum & 0.05 & 0.03 \\
\hline Other extractions & 0.05 & 0.02 \\
\hline Industry & 0.06 & 0.03 \\
\hline Electricity & 0.05 & 0.04 \\
\hline Construction & 0.04 & 0.02 \\
\hline Services & 0.06 & 0.05 \\
\hline Administration & 0.06 & 0.04 \\
\hline
\end{tabular}

Table 3. Impact on household income ( $\%$ change compared to the BAU)

\begin{tabular}{lcc}
\hline & Short-Term & Long-Term \\
\hline Farmers & 0.00 & 0.00 \\
\hline Breeders & 0.02 & 0.02 \\
\hline Public employees & 0.01 & 0.01 \\
\hline Private employees & 0.01 & 0.01 \\
\hline Informal & 0.02 & 0.02 \\
\hline Inactive & 0.02 & 0.02 \\
\hline
\end{tabular}

household categories in both the short and long term (table 3). The increase is not uniform across the different groups and depends on labor and capital endowments for each type of household. As explained above, household income includes wages from labor, capital income, dividends, and transfers from the rest of the world and the government.

For instance, 77 per cent of farmers' household income comes from unskilled labor, while most public employees' income comes from skilled labor. Households rich in capital (breeders for instance) benefit from this policy because of its positive impact on the rental rate of capital. Given the increase in nominal income and the decrease in the consumer prices (see table 1), real household consumption increases for each type of household in both the short and long term (table 4). This increase in household consumption has a positive impact on demand for all commodities - mainly agricultural commodities and services - and therefore on production, but excluding construction, because households do not buy construction commodities as a final good. Household savings and direct taxes increase slightly as well.

Firms' income, exclusively based on capital income, increases throughout the period. Direct taxes, dividends, and savings increase as well. Government income increases 
Table 4. Impact on real household consumption (\% change compared to the BAU)

\begin{tabular}{lcc}
\hline & Short-Term & Long-Term \\
\hline Farmers & 0.03 & 0.01 \\
\hline Breeders & 0.05 & 0.04 \\
\hline Public employees & 0.04 & 0.02 \\
\hline Private employees & 0.03 & 0.02 \\
\hline Informal & 0.05 & 0.03 \\
\hline Inactive & 0.05 & 0.04 \\
\hline
\end{tabular}

slightly, driven by the increase in direct taxes from households and firms, indirect taxes on commodities (given the increase in household consumption), and an increase in capital income. Government savings increase by 0.2 per cent at the end of the period. Given the increase in all agents' savings, total investment increases as well.

\section{Conclusions and policy implications}

The objective of this paper is to assess the macroeconomic effects on employment and economic growth if natural-resource revenue were to be invested in road infrastructure. Indeed, Niger faces many important infrastructure challenges that keep it from reaching a greater GDP and achieving development targets. The discovery of new mining fields provides an opportunity to reinvest in road infrastructure and eventually to avoid the resource curse.

The simulation results show that investment in road infrastructure has positive effects on the economy. Indeed, through the supply effect, other sectors benefit from new roads and bridges and, therefore, can trade more. Through the demand effect, government spending on maintenance stimulates the economy. Overall, unemployment decreases throughout the period while real GDP increases slightly in the long term. Moreover, the increase in real household income could both have an impact on poverty reduction, which is a key objective of the government, and also eventually raise the proportion of the middle class as expected in the Social and Economic Development Plan (PDES). Further work using micro-simulation should be done to capture those microeconomic effects. Therefore, using resource revenues to reinvest in road infrastructure, as suggested in this paper, seems to be an adequate policy to enhance economic growth and eventually mitigate the resource curse. It is thus essential for the government to play a leading role in public spending to drive the economy. In the new PDES (Ministère du Plan, 2017), the conditions for dynamic and job-creating economic growth are expected, notably through the development of quality infrastructure. The results of this paper provide clarification of the effects of such a policy.

It is important to note, however, that this paper evaluates solely an investment in road infrastructure. Further research should investigate investments in water supply, sanitation and power. According to Domínguez-Torres and Foster (2011), less than 10 per cent of the population of Niger is electrified, which represents one-fourth the level of comparable low income countries. Reinvestment of natural-resource revenues into such specific basic infrastructures should be considered by the government as well. 
Acknowledgment. This work was carried out with financial and scientific support from the Partnership for Economic Policy (PEP), with funding from the Department for International Development (DFID) of the United Kingdom (or UK Aid), and the Government of Canada through the International Development Research Centre (IDRC).

\section{References}

Acemoglu D, Johnson S and Robinson J (2003) Botswana. An African success story. In Rodrik D (ed). In Search of Prosperity: Analytical Narratives on Economic Growth. Princeton, NJ: Princeton University Press, 80-119.

Adam C and Bevan D (2006) Aid and the supply side: public investment, export performance and Dutch disease in low income countries. World Bank Economic Review 20(2), 261-290.

Ajakaiye $\mathbf{O}$ and Ncube $\mathbf{M}$ (2010) Infrastructure and economic development in Africa: an overview. Journal of African Economies 19(1), i3-i12.

Alter A, Ghilardi MF and Hakura DS (2016) Public Investment in A Developing Country Facing Natural Resource Depletion. IMF Working papers, No. 15/236, Washington, DC: International Monetary Fund.

Annabi N, Decaluwé B and Cockburn J (2006) Functional forms and parameterization of CGE models, poverty and economic policy. MPIA-PEP Working Paper 2006-04.

Arezki R, Dupuy A and Gelb A (2012) Resource Windfalls, Optimal Investment and Redistribution: The Role of Total Factor Productivity and Administrative Capacity. IMF Working Paper WP/12/200, Washington, DC: International Monetary Fund.

Ayogu M (2007) Infrastructure and economic development in Africa: a review. Journal of African Economies 16(1), 75-126.

Banque de France (2014) Rapport Annuel de la Zone Franc. Available at https:/www.banque-france.fr/ sites/default/files/niger.pdf.

Bategeka L and Matovu JM (2011) Oil Wealth and Potential Dutch Disease Effects in Uganda. Economic Policy Research Center. Research Series No. 81, Kampala, Uganda.

Berg A, Portillo R, Yang SC and Zanna LF (2013) Public investment in resource-abundant developing countries. IMF Economic Review 61(1), 92-129.

Blanchflower DG and Oswald AJ (1995) The Wage Curve. Cambridge, MA: MIT Press.

Bourguignon F and Sundberg M (2006) Constraints to achieving the MDGs with scaled-up aid. DESA Working paper, No. 15. Available at http://www.un.org/esa/desa/papers/2006/wp15 2006.pdf.

Calderón C and Servén L (2008) Infrastructure and Economic Development in Sub-Saharan Africa. World Bank Policy Research Working Paper W4712, Washington, DC: World Bank.

Chitiga M, Mabugu R and Maisonnave H (2016) Analysing job creation effects of scaling up infrastructure in South Africa. Development Southern Africa 33(2), 186-202.

Collier P, Van der Ploeg R, Spence M and Venables A (2010) Managing resource revenues in developing countries. IMF Staff Papers 57(1), 84-118.

Decaluwé B, Lemelin A, Robichaud V and Maisonnave H (2013) PEP-1-t. Standard PEP Model: SingleCountry, Recursive Dynamic Version. Nairobi, Kenya: Partnership for Economic Policy Network.

Domínguez-Torres C and Foster V (2011) Niger's infrastructure: a continental perspective. World Bank Policy Research Working Paper No. 5698. Available at http://econ.worldbank.org.

Esfahani H-S and Ramirez MT (2003) Institutions, infrastructures, and economic growth. Journal of Development Economics 70(2), 443-477.

Estache A, Perrault J and Savard L (2012) The impact of infrastructure spending in Sub-saharan Africa: a CGE modeling approach. Economics Research International 2012, 1-18, doi:10.1155/2012/875287.

Fay M and Yepes T (2003) Investing in Infrastructure. What is needed from 2000 to 2010? Policy Research Working Paper 3102, Washington, DC: The World Bank.

Fedderke J-W and Bogetić Z (2006) Infrastructure and Growth in South Africa: Direct and Indirect Productivity Impacts of 19 Infrastructure Measures. Policy Research Working Paper 3989, Washington, DC: The World Bank.

Go D, Robinson S and Thierfelder K (2016) Natural resource revenue, spending strategies and economic growth in Niger. Economic Modelling 52, 564-573.

Gylfason T and Zoega G (2001) Natural resources and economic growth. European Economic Review 45, $847-885$. 
IMF (International Monetary Fund) (2012a) Niger: request for a new three-year arrangement under the extended credit facility. Staff Report, Press Release on the Executive Board Discussion and Statement by the Executive Director for Niger, Country Report? No. 12/109, Niger.

IMF (International Monetary Fund) (2012b) Macroeconomic Policy Frameworks for Resource-Rich Developing Countries: Analytic Frameworks and Applications. Washington, DC: International Monetary Fund.

IMF (International Monetary Fund) (2015) Niger: Selected Issues. Country Report No. 15/64, Washington, DC: International Monetary Fund.

INS (Institut National de la Statistique) (2013) Comptes Économiques de la Nation. Comptes Rapides 2012. Ministère des Finances, Niamey. Available at http://www.stat-niger.org.

INS (Institut National de la Statistique) (2014) Enquête Nationale sur les Conditions de Vie des Ménages et L'Agriculture (ECVMA). Available at http://www.stat-niger.org/statistique.

INS (Institut National de la Statistique) (2016) Etude Nationale d'Evaluation des Indicateurs SocioEconomiques et Démographiques (ENISED). Available at http://www.stat-niger.org/statistique.

Jung HS and Thorbecke E (2003) The impact of public education expenditure on human capital, growth, and poverty in Tanzania and Zambia: a general equilibrium approach. Journal of Policy Modelling 25(8), $701-725$.

Levy S (2007) Public investment to reverse Dutch disease: the case of Chad. Journal of African Economies 16(3), 439-484.

Ministère du Plan (2017) Plan de Développement Economique et Social (PDES) 2017-2021. Niamey, République du Niger: Ministère du Plan.

Sachs JD and Warner A (1999) The big push, natural resource booms and growth. Journal of Development Economics 59(1), 43-76.

Sachs JD and Warner AM (1995) Economic reform and the process of global integration. Brookings Papers on Economic Activity 1, 1-118.

Sachs JD and Warner AM (2001) The curse of natural resources. European Economic Review 45(4-6), $827-838$.

Sangaré AS, Daouda YH, Boukari M and Ousseini F (2015) Impact de l'essor minier et pétrolier sur le marché du travail et développement économique au Niger. PEP Working Paper 2015-04, Nairobi, Kenya: Partnership for Economic Policy.

Savard L (2010) Scaling up Infrastructure Spending in the Philippines: A CGE top Down Bottom up Microsimulation Approach. Gredi Working Paper 10-06, Sherbrooke, Canada: University of Sherbrooke.

UNDP (United Nations Development Programme) (2017) Human Development Report 2016: Human Development for Everyone. New York, NY: United Nations.

Vanduzai M and Chitiga M (2017) Growth and employment impacts of public economic infrastructure investment in South Africa: a dynamic CGE analysis. Journal of Economic and Financial Sciences 10(2), 235-252.

van der Ploeg F and Poelhekke S (2009) Volatility and the natural resource curse. Oxford Economic Papers 61(4), 727-760.

van der Ploeg F (2011) Natural resources: curse or blessing? Journal of Economic Literature 49(2), 366-420.

Wiebelt M, Pauw K, Matovu JM, Twimukye E and Benson T (2011) Managing future oil revenue in Uganda for agricultural development and poverty reduction: a CGE analysis of challenges and options. IFPRI Discussion Paper 01122.

World Bank (2002) World Bank Annual Report 2002: Main Report. Washington, DC: World Bank. Available at http://documents.worldbank.org/curated/en/379051468163155729/Main-report.

World Bank (2016) The World Bank Annual Report 2016. Washington, DC: World Bank. Available at https://openknowledge.worldbank.org/handle/10986/24985.

Cite this article: Sangare S, Maisonnave H (2018). Mining and petroleum boom and public spending policies in Niger: a dynamic computable general equilibrium analysis. Environment and Development Economics 23, 580-590. https://doi.org/10.1017/S1355770X18000104 